\title{
MAGEA11 Gene
}

National Cancer Institute

\section{Source}

National Cancer Institute. MAGEA11 Gene. NCI Thesaurus. Code C91336.

This gene is involved in androgen receptor function. 